\title{
Kompleksowa analiza ryzyka środowiskowego dla procesów poszukiwania i eksploatacji niekonwencjonalnych złóż węglowodorów typu shale gas w Polsce
}

\begin{abstract}
Poszukiwanie i wydobycie gazu ze złóż niekonwencjonalnych typu shale gas może stwarzać potencjalne zagrożenia dla środowiska. Praca prezentuje propozycję analizy ryzyka środowiskowego, która może być wstępem do zarządzania ryzykiem podczas procesów poszukiwania i wydobycia gazu z łupków w warunkach polskich.
\end{abstract}

Słowa kluczowe: analiza ryzyka środowiskowego, zrównoważony rozwój, gaz z łupków, wiertnia, zanieczyszczenie środowiska.

\section{Complex environmental risk assessment for the exploration and extraction processes of unconventional hydrocarbon deposits of the shale gas type in Poland}

Shale gas exploration and extraction processes create a potential threat to the environment. This paper presents an environmental risk assessment which can be used for the risk management during shale gas exploration and extraction processes in Polish conditions.

Key words: environmental risk assessment, sustainable development, shale gas, drilling rig, environment pollution.

\section{Wprowadzenie}

Nasza cywilizacja jest ściśle związana z koniecznością pozyskiwania naturalnych surowców energetycznych. Saudyjczycy często mawiają: „Mój ojciec jeździł na wielbłądzie. Ja jeżdżę samochodem. Mój syn lata odrzutowcem. Jego syn będzie jeździł na wielbłądzie" ze świadomością, że źródło tego bogactwa nie jest wieczne, a wyczerpać się może szybciej, niż ktokolwiek przypuszcza. Intensywne poszukiwania energetycznej alternatywy na najbliższe stulecia doprowadziły do skierowania uwagi na pokłady gazu, wszechobecnego na kuli ziemskiej, z których dotychczas nie korzystano na masową skalę, czyli gazu z łupków.

Każdy przemysł oddziałuje na środowisko. Szybkie tempo wykorzystania zasobów naturalnych narusza równowagę ekologiczną, a ryzyko ich wyczerpania i zanieczyszczenie spowodowane ich wykorzystaniem stanowi coraz większe zagrożenie. Tendencje do załamania gospodarki światowej w wyniku zużycia zasobów nieodnawialnych prognozuje między innymi raport Granice wzrostu [8].

Aby odwrócić tendencję niezrównoważonego wykorzystania zasobów oraz powstrzymać degradację środowiska naturalnego polityka ochrony środowiska musi wyjść poza zwykłą kontrolę zanieczyszczeń i opłaty za korzystanie ze środowiska. Duże wyzwanie stanowi eliminacja ryzyka związanego z ludzką działalnością. Kompleksowa analiza ryzyka jest wstępem do zarządzania nim i daje szanse nie tylko na ograniczenie strat środowiskowych, ale i na poprawę wyników finansowych firm. Racjonalne zarządzanie ryzykiem potrafi dostarczyć zarządzającym wielu cennych informacji na temat potencjalnych skutków różnych decyzji. Ryzyko środowiskowe jest częścią całkowitej i pogłębionej analizy ryzyka prowadzonej w przedsiębiorstwie. Zidentyfikowane ryzyka środowiskowe gwarantują bezpieczne funkcjonowanie inwestycji w przyszłości. 


\section{Środowiskowe aspekty procesów poszukiwania, wydobycia i eksploatacji gazu z łupków}

Proces oddziaływania człowieka na środowisko rozpoczął się już w neolicie i stopniowo z rozwojem technologii obejmował coraz większe obszary naszego globu. Pierwsze konsekwencje ekologiczne były wprawdzie niewielkie, jednak proces coraz głębszej ingerencji w strukturę ekosystemów nie został już nigdy w historii zatrzymany. Wszystkie procesy wydobycia należy zaliczyć do grupy destrukcyjnych. Problem wydaje się jednak nieco bardziej złożony, ponieważ o ile pod ziemią prowadzimy procesy destrukcyjne i destabilizujące formacje geologiczne, to z drugiej strony wydobycie kopalin pozwala nam egzystować na powierzchni ziemi, rozwijać się, przemieszczać oraz ogrzewać się i produkować niezbędne przedmioty codziennego użytku. Sferą domniemywań pozostają natomiast ewentualne skutki dla środowiska naturalnego, jakie przyniesie w przyszłości proces wydobycia gazu z łupków.

Dyskusja na temat tego, czy zaburzamy naturalną równowagę przyrody, rozpoczyna się może nie tyle podczas poszukiwań złóż kopalin, co podczas ich wydobycia.

Poszukiwanie gazu z łupków to przede wszystkim rozpoznanie budowy geologicznej za pomocą fal akustycznych, które generowane są przez urządzenia zainstalowane w pojazdach ciężarowych, tzw. wibratorach (tłuczkach). Jeżeli wynik okaże się pozytywny, w pierwszej kolejności wykonywany jest odwiert próbny, umożliwiający dokładne zbadanie rdzenia geologicznego. W przypadku pozytywnej oceny opłacalności rozpoczyna się prace związane z wydobyciem gazu, które poprzedzone są uzyskaniem koncesji na eksploatację. Drugim etapem jest przygotowanie powierzchni od $2 \div 4$ ha na budowę wiertni wraz z infrastrukturą towarzyszącą. Po niwelacji terenu zebrana warstwa humusu jest deponowana w formie wałów dokoła placu. Eksploatacja złóż gazu z łupków wiąże się z czasowym wyłączeniem gruntu z produkcji rolniczej oraz ze zmianą sposobu jego użytkowania. Istnieje przy tym potencjalna możliwość zanieczyszczenia gleby i ziemi paliwami, olejami czy substancjami chemicznymi służącymi do przygotowania płuczki. Aby wykluczyć zanieczyszczenie wód podziemnych „od strony” otworu wiertniczego, odwierty są cementowane i omurowywane. Pod urządzeniem wiertniczym wydzielona jest tzw. strefa brudna, odizolowana od pozostałej części placu systemem drenarskim, za pomocą którego woda opadowa zostaje odprowadzona do szczelnego zbiornika. Mieszaniny chemiczne w fabrycznych opakowaniach są magazynowane w miejscach osłoniętych przed wpływami atmosferycznymi na szczelnym, utwardzonym podłożu, podobnie jak zbiorniki na paliwa, oleje i smary. Przykładowy wygląd placu wiertniczego przedstawiono na rysunku 1 . Wszelkie wytworzone ścieki bytowe muszą być gromadzone oraz sukcesywnie wywożone do oczyszczalni.
Aby przyszła wiertnia mogła funkcjonować, niezbędne jest doprowadzenie energii elektrycznej oraz dróg dojazdowych. Najlepiej, aby była usytuowana blisko źródła wody, która będzie niezbędna w procesach wydobycia. Po zamontowaniu wieży wiertniczej następuje etap wiercenia pionowego. Odbywa się ono przy udziale płuczek wiertniczych, mających za zadanie odprowadzić zwierciny na powierzchnię. Zwykle wiercenie pionowe sięga do głębokości $3 \div 4,5 \mathrm{~km}$. Długość

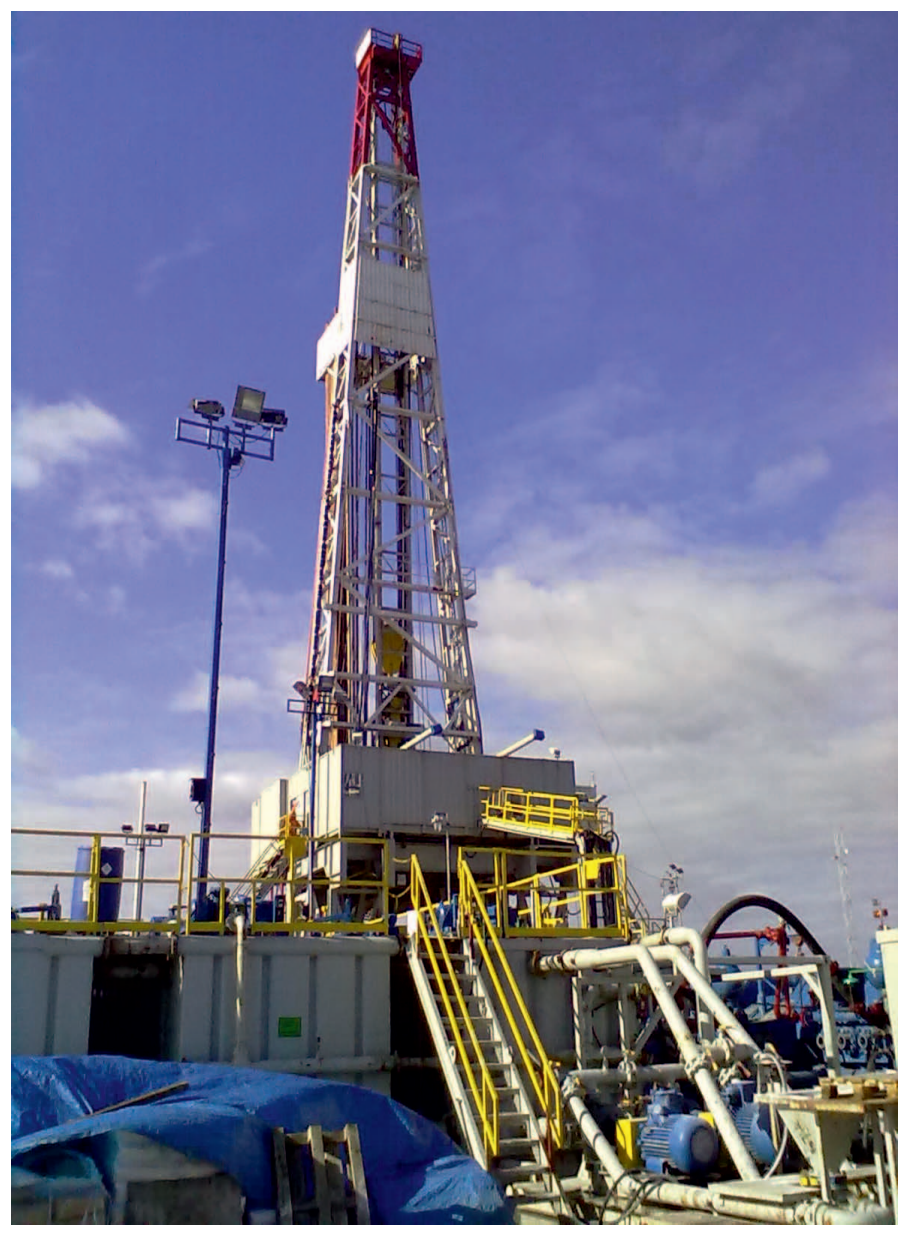

Rys. 1. Przykładowy widok wiertni shale gas

odwiertu horyzontalnego wynosi zwykle $1 \div 2 \mathrm{~km}$. Na tej długości również umieszcza się rury okładzinowe i wykonuje cementowanie. Zaletą wiercenia horyzontalnego jest możliwość prowadzenia odwiertu w różnych kierunkach, dzięki czemu wykorzystując małą powierzchnię na ziemi, można wykonać wiele odwiertów.

Po etapie wiercenia wiertnia jest demontowana. Udostępnianie złoża odbywa się za pomocą pomp o mocy wielu tysięcy koni mechanicznych, silosów na proppant i urządzeń wspomagających. Dodatkowo zostaje także wykonany zbiornik na wodę wykorzystywaną do przygotowania płynu szczelinującego. To tymczasowa ingerencja w krajobraz, gdyż trwa od kilku 
do kilkunastu tygodni, a po udostępnieniu złoża sprzęt jest wywożony. Technologia szczelinowania hydraulicznego polega na wpompowywaniu do otworu poziomego płynu szczelinującego o składzie dostosowanym do stymulowanego złoża pod wysokim ciśnieniem, co powoduje kruszenie skały i powstawanie szczelin, które umożliwiają migrację gazu ze złoża do odwiertu. Pod wpływem wytwarzanych naprężeń - szczeliny w skałach łupkowych pękają i powiększają się. W otworach poziomych wykonywanych jest średnio od 10 do 12 zabiegów hydraulicznego szczelinowania, co wymaga zużycia około $20000 \mathrm{~m}^{3}$ płynu szczelinującego i 4000 ton materiału podsadzkowego [10]. Głównym składnikiem płynu szczelinującego jest woda, która stanowi około 90\% składu, i piasek jako materiał podsadzkowy - 9 $\div 9,5 \%$ składu. Dodatki do wody to składniki chemiczne powszechnie znane i używane w gospodarstwach domowych. Środki zmiękczające wodę i zapobiegające korozji stanowią 0,49\% składu.
Po zakończeniu szczelinowania hydraulicznego na placu zostaje jedynie głowica hydrauliczna oraz urządzenia związane $\mathrm{z}$ wydobyciem gazu z odwiertu i przesyłem do sieci gazociągowej. Przewiduje się, że etap eksploatacji gazu z łupków może trwać $30 \div 35$ lat. Po jej zakończeniu odwiert należy zacementować i odciąć na głębokości kilkunastu metrów pod ziemią. Po przeprowadzeniu rekultywacji terenu nie zostaje najmniejszy widoczny ślad po uprzedniej działalności wydobywczej.

Wiele osób zarzuca, że wydobycie gazu z łupków może powodować trzęsienia ziemi. Jednak z raportu Instytutu Geofizyki PAN [11] wynika, że rejestrowane podczas procesów szczelinowania hydraulicznego drgania nie przekraczają dopuszczalnych wartości według polskiej normy PN-85/B-02170, a większość z nich jest zbyt niska, aby mogła być odczuwalna na powierzchni. Prewencyjnie zaleca się jednak prowadzenie monitoringu sejsmicznego [1].

\section{Przegląd światowych wytycznych i metod oceny ryzyka środowiskowego}

Analiza ryzyka środowiskowego wywodzi się z analizy wpływu na człowieka substancji i związków chemicznych produkowanych, stosowanych i uwalnianych do środowiska. Pierwsze dokumenty poświęcone analizie ryzyka powstawały w USA już od 1975 roku [12]. W latach 80. XX wieku EPA (Environmental Protection Agency) uruchomiła Zintegrowany System Informacji o Ryzyku (IRIS) - bazę danych o skutkach dla zdrowia człowieka, które mogą wyniknąć z narażenia na działanie różnych substancji występujących w środowisku.

Zgodnie z definicją EPA [13] analiza ryzyka to proces określający prawdopodobieństwo wystąpienia negatywnych skutków w środowisku w wyniku narażenia organizmów żywych na działanie jednego lub więcej czynników stresogennych. Dokument Framework for ecological risk assessment [13] rozróżnia analizę ryzyka ekologicznego (czyli ocenę bezpieczeństwa użytkowania środków chemicznych, powstających odpadów niebezpiecznych, emisji do środowiska, wpływu na bioróżnorodność, zmiany krajobrazu, wpływu na zasoby wodne) oraz analizę ryzyka dla zdrowia ludzi jako efekt oddziaływania czynników stresogennych. Rozszerzeniem i aktualizacją powyższych zagadnień jest dokument Guidelines for Ecological Risk Assessment [14], w którym podkreślono, że ocena ryzyka i zarządzanie ryzykiem to dwa odrębne działania. Składają się na nie: ocena ryzyka dla zdrowia ludzi i ocena ryzyka dla środowiska naturalnego. Opisują one populacje ludzkie, zasoby i środki ekologiczne, charakteryzują potencjał działań niepożądanych, definiują niepewności, wskazują możliwości radzenia sobie z zagrożeniami i przekazują informacje na temat zagrożeń dla ludzi i ekosystemów. W raporcie Environmental risk assessment: An Australian perspective [2] pokazano, że ocena ryzyka dla środowiska może być stosowana jako strategiczne narzędzie w działalności przedsiębiorstw. Idąc za tym przykładem, warto posłużyć się kolejnymi wytycznymi - Environmental risk assessment (ERA): An approach for assessing and reporting environmental conditions [9] jako pomocą w zakresie oceny i raportowania warunków środowiskowych.

Analizę ryzyka środowiskowego zawsze należy rozpatrywać $\mathrm{w}$ formie studium przypadku z rozrysowanym diagramem lub mapą zidentyfikowanych obszarów dla konkretnego ryzyka, począwszy od źródła jego powstania, poprzez drogi migracji, aż do odbiorcy [6]. Powyższe instrukcje i przewodniki mogą służyć jako baza wyjściowa do przeprowadzania oceny ryzyka i zarządzania nim.

W przepisach Unii Europejskiej procedury oceny ryzyka zostały określone w dyrektywie Komisji 93/67/EWG z 20 lipca 1993 roku w sprawie zasad oceny ryzyka dla ludzi i środowiska ze strony substancji dopuszczonych do obrotu w związku z dyrektywą 67/548/EWG [15]. Nie oznacza to jednak, że wytyczne odnoszą się wyłącznie do substancji chemicznych, można za ich pomocą analizować ryzyko związane z emisją hałasu, zmianą krajobrazu czy stosunków wodnych.

W Polsce sposób dokonywania oceny ryzyka dla zdrowia i środowiska regulują: ustawa z 11 stycznia 2001 roku o substancjach i preparatach chemicznych [17] oraz rozporządzenie Ministra Zdrowia z 12 stycznia 2005 roku w sprawie sposobu dokonywania oceny ryzyka dla zdrowia człowieka i dla środowiska stwarzanego przez substancje nowe [16]. Sama ustawa - Prawo ochrony środowiska [18] nie wymaga przeprowadzenia analizy ryzyka, jednak można wywnioskować, że analiza ta powinna stanowić część etapu oceny oddziaływania 
na środowisko. W przypadku zakładów kwalifikowanych jako zakłady zwiększonego (ZZR) lub dużego ryzyka (ZDR) wystąpienia awarii przemysłowych - przepisy prawa nakładają na operatora obowiązek przygotowania programu zapobiega- nia awariom oraz raportu o bezpieczeństwie. Takie dokumenty można śmiało nazwać wstępem do analizy ryzyka, ponieważ analizują prawdopodobieństwo wystąpienia awarii na terenie zarządzanego zakładu.

\section{Propozycja analizy ryzyka dla procesów poszukiwania i eksploatacji niekonwencjonalnych złóż węglowodorów w Polsce}

Ryzyko nieodłącznie towarzyszy człowiekowi i jego otoczeniu. To pojęcie wieloznaczne i złożone. Może być definiowane jako ewentualność wystąpienia jakiegoś wydarzenia, którego urzeczywistnienie będzie miało negatywny wpływ na realizację zamierzonego celu, bądź jako możliwość wystąpienia niechcianej sytuacji, mogącej wpłynąć na obniżenie poziomu sukcesu [5], bądź jako miara prawdopodobieństwa zaistnienia niezadowalającego rezultatu, wpływającego na projekt, proces lub produkt. Ryzyko może być badane w różnych kontekstach. Ryzyko środowiskowe [3] to zgodnie z definicją - rzeczywiste lub potencjalne zagrożenie identyfikowane jako negatywny wpływ na organizmy żywe i środowisko wynikające z działalności danej organizacji. Bardzo ważne jest przy tym rozróżnienie pojęcia zagrożenia - ang. hazard (sytuacja, która w określonych okolicznościach może prowadzić do powstania szkód) oraz pojęcia ryzyka - ang. risk (iloczyn prawdopodobieństwa zajścia zdarzenia powodującego zagrożenie oraz skali jego negatywnych skutków), ponieważ wytypowanie zagrożeń nie stanowi jeszcze określenia ryzyka.

Na potrzeby oceny wpływu planowanych prac poszukiwawczych i eksploatacyjnych na środowisko oraz zagrożeń, jakie mogą wystąpić ze strony określonych elementów środowiskowych i ludzi, wyróżniono trzy główne etapy prac i następujące czynności:

1) faza poszukiwawczo-rozpoznawcza: prace sejsmiczne, wiercenia otworów rozpoznawczych, szczelinowanie hydrauliczne w pojedynczym otworze, próbna eksploatacja odwiertu lub jego likwidacja, likwidacja wiertni i rekultywacja terenu, przygotowanie padu do rozpoczęcia przemysłowego wydobycia gazu,

2) faza przemysłowego wydobywania gazu: wstępne wydobycie $\mathrm{z}$ otworów wykonanych na etapie prac rozpoznawczych i budowa infrastruktury zakładu górniczego, wiercenie nowych odwiertów eksploatacyjnych (na istniejących padach lub organizacja nowych padów w obrębie obszaru i terenu górniczego), szczelinowanie nowo odwierconych otworów eksploatacyjnych, rozbudowa infrastruktury zakładu górniczego,

3) faza zakończenia eksploatacji: stopniowe zmniejszanie wydobycia gazu, likwidacja odwiertów, całkowita likwidacja zakładu górniczego, rekultywacja terenu.
Do najczęściej wymienianych zagrożeń środowiskowych mogących wystąpić podczas poszukiwania i eksploatacji niekonwencjonalnych złóż węglowodorów należą [7]:

- degradacja gleb poprzez budowę wiertni i dróg dojazdowych,

- zmiana rzeźby terenu,

- lokalne zanieczyszczenie powierzchni ziemi i gruntów paliwami, środkami myjącymi oraz materiałami służącymi do sporządzania płuczek wiertniczych, gruzem, cementem, żwirem,

- zanieczyszczenie wód powierzchniowych oraz podziemnych w wyniku awaryjnego odprowadzania do nich ścieków, przenikania zanieczyszczeń ze zbiorników odpadów,

- zachwianie równowagi hydrogeologicznej poprzez znaczny pobór wód,

- emisje hałasu oraz zanieczyszczeń atmosferycznych powstałych w wyniku spalania paliw.

Analiza ryzyka środowiskowego powinna stanowić integralną część analiz ryzyka w przedsiębiorstwie, być realizowana w sposób systematyczny, opierać się na najświeższych informacjach i najlepszych technikach oraz ciągle się doskonalić [4]. W tym celu po zidentyfikowaniu potencjalnych przypadków ryzyka należy ocenić prawdopodobieństwo ich wystąpienia. Najlepszym rozwiązaniem jest zastosowanie kombinacji metody jakościowej (opartej na dobrych praktykach i doświadczeniu) oraz ilościowej, określającej wartości skutku i prawdopodobieństwa wystąpienia danego ryzyka. Szacowanie i wyniki otrzymane według tej oceny są obiektywne i porównywalne.

Zaproponowany sposób przeprowadzania analizy ryzyka zawiera listę kluczowych zagrożeń środowiskowych możliwych do wystąpienia na etapie poszukiwań, eksploatacji oraz zakończenia prac, których pojawienie się w analizowanym projekcie generuje ryzyko (tablica 2). Jeśli opisane zagrożenie występuje na danym etapie, oznaczamy je symbolem (V), jeśli nie występuje, opisujemy je jako (X). Następnie należy określić prawdopodobieństwo zaistnienia analizowanego zdarzenia, możliwy wpływ, opisać ryzyko oraz określić sposób jego minimalizowania. Prawdopodobieństwo wystąpienia ryzyka określono za pomocą matrycy ryzyka (tablica 1).

Poziom ryzyka mierzony jest jako wypadkowa prawdopodobieństwa wystąpienia analizowanego zdarzenia oraz skali jego negatywnych skutków dla środowiska i człowieka. Zakłada się przy tym, że: 
Tablica 1. Matryca ryzyka (opracowanie własne)

\begin{tabular}{|l|c|c|c|c|}
\cline { 3 - 5 } \multicolumn{2}{c|}{} & \multicolumn{3}{c|}{ Prawdopodobieństwo wystąpienia zdarzenia } \\
\hline \multirow{2}{*}{ Skutki dla środowiska i człowieka } & $\begin{array}{c}\text { 1 raz w roku lub } \\
\text { wcale }\end{array}$ & $\begin{array}{c}\text { więcej niż 1 raz } \\
\text { w roku }\end{array}$ & $\begin{array}{c}\text { wielokrotnie } \\
\text { w ciągu roku }\end{array}$ \\
\cline { 3 - 5 } & 1 małe & 2 średnie & 3 duże \\
\hline $\begin{array}{l}\text { Niewielki wpływ na } \\
\text { środowisko i człowieka }\end{array}$ & 1 małe & ryzyko małe & ryzyko małe & ryzyko średnie \\
\hline $\begin{array}{l}\text { Znaczący wpływ na } \\
\text { środowisko i człowieka }\end{array}$ & 2 średnie & ryzyko małe & ryzyko średnie & ryzyko duże \\
\hline $\begin{array}{l}\text { Duży wpływ na } \\
\text { środowisko i człowieka }\end{array}$ & 3 duże & ryzyko małe & ryzyko duże & ryzyko duże \\
\hline
\end{tabular}

- ryzyko duże występuje, gdy analizowane zdarzenie może wystąpić wielokrotnie w ciągu roku lub w najbliższym terminie oraz spowoduje duży wpływ na środowisko i człowieka,

- ryzyko średnie - gdy analizowane zdarzenie może wystąpić więcej niż 1 raz w roku oraz spowoduje znaczący wpływ na środowisko i człowieka,

- ryzyko małe - gdy analizowane zdarzenie może wystąpić 1 raz w roku lub wcale oraz spowoduje niewielki wpływ na środowisko i człowieka.

W arkuszu analizy ryzyka (tablica 2 ) znajduje się informacja o poziomie ryzyka określonym na podstawie prawdopodobieństwa wystąpienia analizowanej sytuacji/zdarzenia i oceny łącznego wpływu na projekt, zgodnie z matrycą ryzyka (tablica 1). Ze względu na zmieniające się uwarunkowania lokalne, przyrodnicze, społeczne - dla każdej lokalizacji prac wymagane jest przeprowadzenie odrębnej oceny ryzyka środowiskowego. Taka analiza będzie wtedy bardziej wiarygodna. Docelowo dla każdego przypadku ryzyka powinny zostać określone działania minimalizujące i proponowane metody zarządzania ryzykiem.

Podczas planowania inwestycji związanych z eksploatacją niekonwencjonalnych złóż węglowodorów pracownicy służb ochrony środowiska korzystają z danych przestrzennych systemu map Geoserwis dotyczących m.in. form ochrony przyrody w Polsce, których działanie koordynuje Generalny

Tablica 2. Arkusz analizy ryzyka (opracowanie własne)

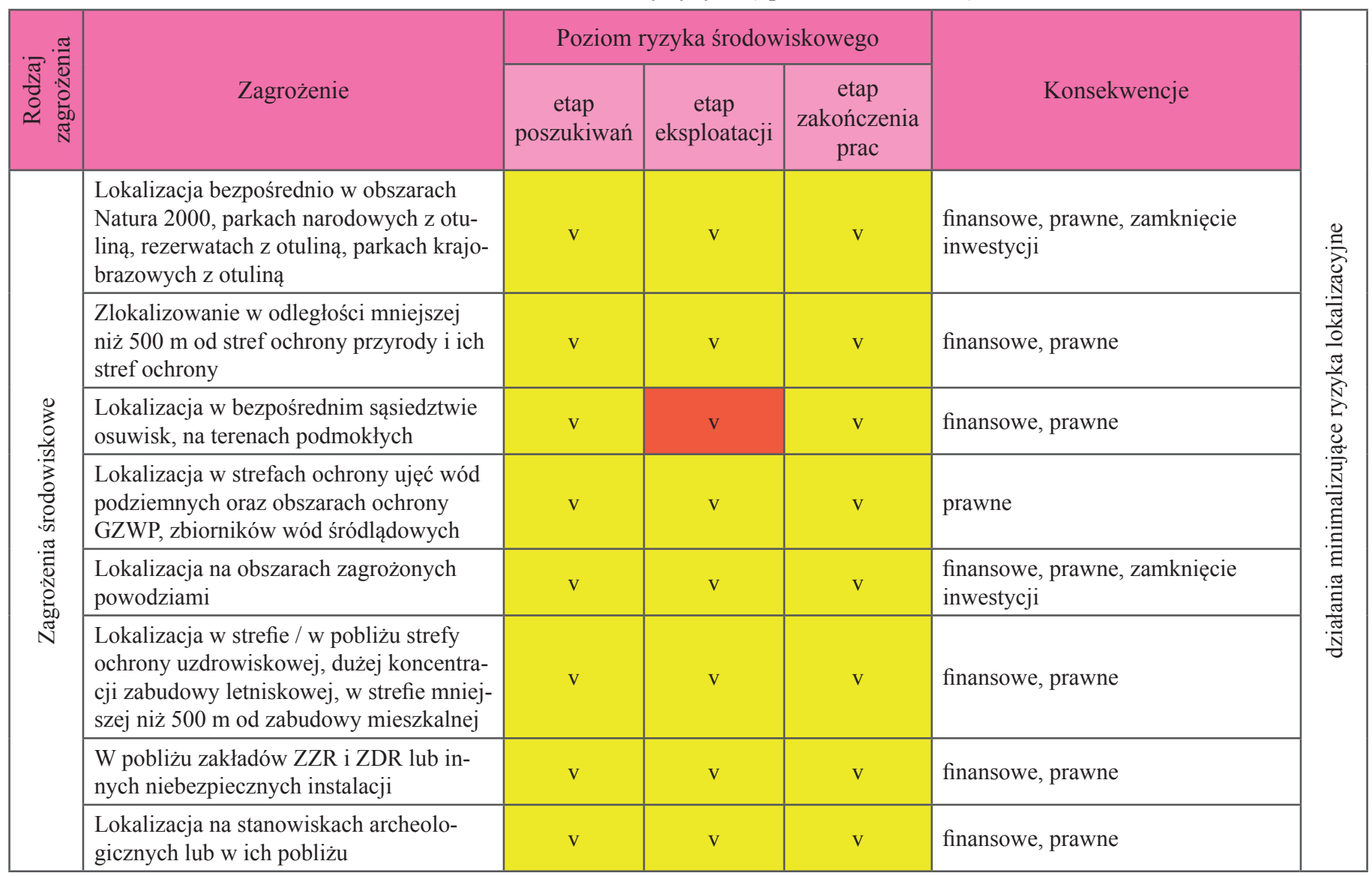


cd. Tablica 2

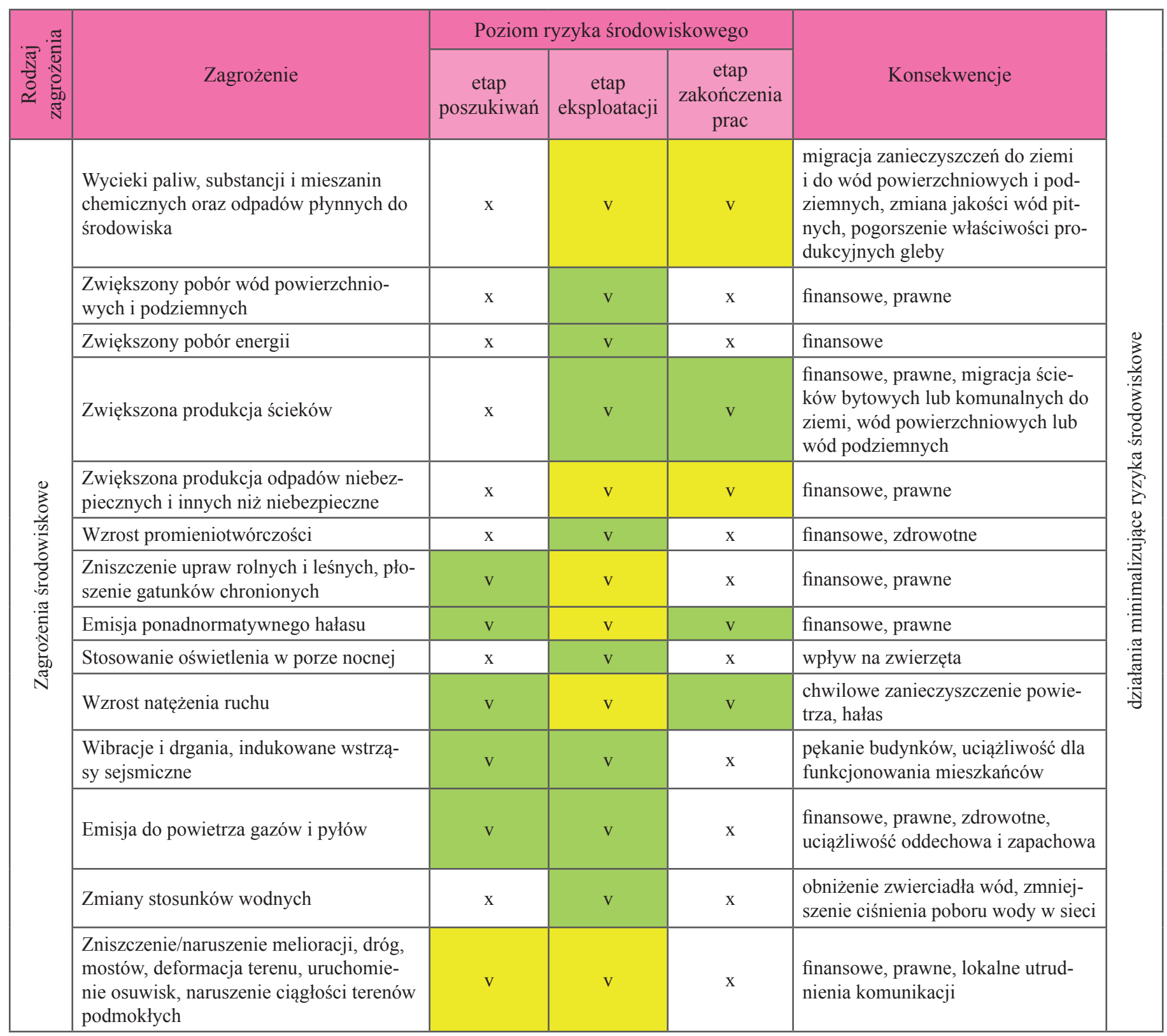

Dyrektor Ochrony Środowiska. Połączenie informacji zawartych w arkuszu analizy ryzyka (tablica 2) z programem Arc Gis, przeznaczonym do pracy na danych GIS (systemów informacji przestrzennej), za pomocą aplikacji dedykowanej może stanowić kompleksowe narzędzie wspomagające pracę w zakre- sie zarządzania ryzykiem. Po oznaczeniu na mapie danej lokalizacji inwestor otrzymywałby szybką informację zwrotną o potencjalnych ryzykach środowiskowych. Takie rozwiązanie daje możliwość profesjonalnego wspomagania decyzji w zakresie eksploatacji niekonwencjonalnych złóż węglowodorów.

\section{Wnioski}

Przedstawiony model analizy ryzyka środowiskowego pozwala na identyfikację kluczowych przypadków ryzyka wpływających na realizację prac związanych z poszukiwaniem i eksploatacją niekonwencjonalnych złóż węglowodorów w warunkach polskich. Rezultatem tej identyfikacji jest rejestr ryzyka. Kolejnym krokiem powinno być wypracowanie schematów radzenia sobie z ryzykiem poprzez podejmowanie działań minimali- zujących. Poziom ryzyka środowiskowego oznaczony kolorem czerwonym w arkuszu analizy ryzyka (tablica 2) informuje, że dane zagrożenie implikuje duże ryzyko, które jest nieakceptowalne i wymaga natychmiastowego działania oraz monitorowania. Kolor żółty wskazuje ryzyko średnie, wymagające monitorowania, zaś kolor zielony - ryzyko małe, znikome i wymagające okresowej weryfikacji bez konieczności monitorowania. 
Ponieważ ryzyko środowiskowe ma charakter dynamiczny, oceniający je są zobligowani do jego ciągłego monitoro- wania i uwzględnienia wyników tego monitoringu w strategii zarządzania ryzykiem.

Prosimy cytować jako: Nafta-Gaz 2018, nr 3, s. 208-214, DOI: 10.18668/NG.2018.03.04

Artykuł nadesłano do Redakcji 7.11.2017 r. Zatwierdzono do druku 9.02.2018 r.

\section{Literatura}

[1] Baisch S., Pater C.J.: Geomechanical Study of Bowland Shale Seismicity. Synthesis Report. Technical report, 2011.

[2] Beer T., Ziolkowski F.: Environmental risk assessment: An Australian perspective. EPA, Australia, 1995.

[3] Borysiewicz M., Kacprzyk W., Potempski S., Żurek J.: Wytyczne oceny ryzyka środowiskowego. Instytut Ochrony Środowiska, Warszawa 2005.

[4] Gasiński T., Pijanowski S.: Zarzadzanie ryzykiem w procesie zrównoważonego rozwoju biznesu. Ministerstwo Gospodarki, Warszawa 2011.

[5] Górski M.: Rynkowy system finansowy. PWN, Warszawa 2009.

[6] Guidelines for environmental risk assessment and management Green Leaves III. Defra, UK 2011.

[7] Macuda J.: Środowiskowe aspekty produkcji gazu ziemnego z niekonwencjonalnych złóż. Przegląd Geologiczny 2010, vol. 58 , s. 266-270.

[8] Meadows D.H., Meadows D.L., Randers J., Behrens W.W.: Granice wzrostu. Państwowe Wydawnictwo Ekonomiczne, Warszawa 1973.

[9] Ministry of Environment, Lands and Parks (British Columbia): Environmental risk assessment (ERA): An approach for assessing and reporting environmental conditions. Technical Bulletin 1, July 2000.

[10] Państwowy Instytut Geologiczny - Państwowy Instytut Badawczy: Badania aspektów środowiskowych procesu szczelinowania hydraulicznego wykonanego w otworze Lebień LE-2H. Warszawa 2011.

[11] Plesiewicz B., Suchcicki J., Wiszniowski J.L.: Monitoring sejsmiczny szczelinowania hydraulicznego na otworze Łebień $L E-2 H$. Narodowy Fundusz Ochrony Środowiska i Gospodarki Wodnej, Instytut Geofizyki PAN 2011.

[12] Risk Assesment, strona internetowa EPA, https://www.epa.gov/ risk/about-risk-assessment (dostęp: 9.10.2017).
[13] US Environmental Protection Agency: Framework for Ecological Risk Assessment. Washington 1992.

[14] US Environmental Protection Agency: Guidelines for Ecological Risk Assessment. Washington 1998.

\section{Akty prawne i normatywne}

[15] Dyrektywa Komisji 93/67/EWG z dnia 20 lipca 1993 r. ustanawiająca zasady oceny ryzyka dla człowieka i środowiska naturalnego ze strony substancji notyfikowanych zgodnie z dyrektywą Rady 67/548/EWG.

[16] Rozporządzenie Ministra Zdrowia z dnia 12 stycznia 2005 r. W sprawie sposobu dokonywania oceny ryzyka dla zdrowia człowieka i dla środowiska stwarzanego przez substancje nowe (Dz.U. z 2005 r. Nr 16, poz. 138).

[17] Ustawa z dnia 11 stycznia $2001 \mathrm{r}$ o substancjach i preparatach chemicznych (Dz.U. z 2005 r. Nr 16, poz. 138).

[18] Ustawa z dnia 27 kwietnia 2001 r. - Prawo ochrony środowiska (Dz.U. z 2013 r., poz. 1232).

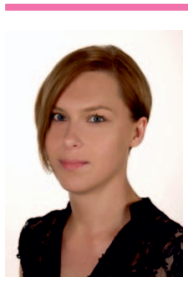

Mgr Monika WÓJCIK

Główny Specjalista ds. Ochrony Środowiska PGNiG SA

Centrala Spółki

ul. M. Kasprzaka 25

01-224 Warszawa

E-mail:monika.wojcik@pgnig.pl 